\title{
Effect of Organic Manure on Nutrient Contents of Rice Grown in an Arsenic Contaminated Soil
}

\author{
R. Ashrafi, ${ }^{a}$ M. H. R. Biswas, ${ }^{b}$ G. K. M. Mustafizur Rahman, ${ }^{b *}$ R. Khatun ${ }^{a}$ and M. R. Islam ${ }^{a}$ \\ ${ }^{a}$ Department of Soil Science, Bangladesh Agricultural University, Mymensingh-2202, Bangladesh and \\ ${ }^{b}$ Bangabandhu Sheikh Mujibur Rahman Agricultural University, Gazipur 1706, Bangladesh
}

\begin{abstract}
A pot experiment was carried out to study the effects of organic manures on nitrogen, phosphorus, potassium and sulphur concentrations in grain, husk, stem and root of rice grown in an arsenic contaminated soil. Randomized Complete Block Design with three replications was followed where each pot received an equal amount of N, P, K and S to sustain normal plant growth. N, P, K and S concentration in grain, husk, straw and root of rice plant were increased with organic manure application compared to control treatment. This study considered rice husk and root along with grain and straw as they have value to increase soil nutrient by recycling. Arsenic contamination becoming a concerning issue because its contamination in many agricultural soil is increasing following contamination in groundwater. This study concluded that organic manure is effective in arsenic contaminated soil to increase $\mathrm{N}, \mathrm{P}, \mathrm{K}$ and $\mathrm{S}$ concentration in rice plant.
\end{abstract}

Key words : Organic manure, Nutrient, Rice plant, Arsenic contaminated soil

\section{Introduction}

Soil degradation is said to be occurring in Bangladesh due to the intensification of crop cultivation and the advance of monoculture rice and providing imbalance nutrient base to their crop with the increasing cropping intensity. The use of chemical fertilizer is also increasing in Bangladesh. Soil fertility is degraded due to indiscriminate and inefficient use of chemical fertilizer (Rahman and Moral, 2006). Soil for intensive crop cultivation without replenishing it with nutrients is causing nutrient mining to an extent that ultimately will make it barren. The fertility of most of our soils has deteriorated over the years (Ali et al., 1997) which is responsible for national yield stagnation and in some cases, even declining crop yields (Cassman et al., 1997). The decline or stagnation of major crop yields in Bangladesh is the cumulative effect of many soil related constraints among them the important ones are depletion of soil organic matter, nutrient mining, scant use of bio and organic fertilizer and poor management practices (Hossain, 2001). Where a good soil should have more than 3.5\% organic matter in Bangladesh, most soils have less than $1.7 \%$ and some soils have even less than 1\% organic matter (Fertilizer Recommendation Guide, 2005). Yet, the country achieved impressive gains in food grain production by increasing fertilizer use, investing in irrigation and adopting modern seed varieties (Rahman and

\footnotetext{
* Corresponding author: E-mail: hiyamustafiz@yahoo.com
}

Moral, 2006). Most of the soils of Bangladesh show an improved response when organic matter is incorporated along with inorganic fertilizers. The availability of N, P and $\mathrm{K}$ increased in the soil with the addition of organic amendments, either alone or in combination with inorganic fertilizers (Khatik and Dikshit, 2001).

Organic matter is a complex and dynamic soil component that exerts a major influence on soil behaviour, properties and function in the ecosystem. Organic matter greatly enhances the usefulness of soils for plant production. Nitrogen, phosphorus, sulphur and micronutrients are stored as constituents of soil organic matter until released by mineralization. Organic manure significantly increased soil organic matter content, EDTA-extractable $\mathrm{Fe}, \mathrm{Zn}, \mathrm{Cu}$ and plant available N, P and K (Rezaenejad and Afyuni, 2001). Organic substances dissolve phosphorus, calcium and magnesium carbonates and other compounds by various products of microbial activity and organic acids associated with humus also accelerate the release of nutrient elements from mineral structures (Brady and Weil, 1996). All these phenomena are undoubtedly of very great importance in the soil because they are responsible for bringing about the conversion of a number of chemical elements into forms available to plants. 
In 52 districts among the 64 districts of Bangladesh, the groundwater arsenic value exceeded the recommended value of WHO (0.01 mg/L) (Dhar et al., 1997). Significant positive correlation was observed between groundwater arsenic and total arsenic levels in surface as well as sub-surface soils (Biswas et al., 2003). As many agricultural soils in Bangladesh are becoming contaminated with arsenic, there is a need to observe the organic matter effect on nutrient availability in soil and transfer of nutrients from soil to plant organ. A number of reports are available on the nutrient contents of rice grain and straw but very few reports are available on the nutrient contents of rice husk and root. Rice husks are usually used as fuel and at the end the ashes are being recycled to the crop fields. Plant roots are being recycled in the crop fields. It would be important to know the nutrients contents of rice husk and straw to know the amount of nutrients being recycled in the rice fields. Therefore, a pot experiment was conducted to investigate the role of different manures on nutrient partitioning in Boro rice grown on an arsenic contaminated soil.

\section{Materials and Methods}

Arsenic contaminated soils were collected from Krishnagar union of Faridpur Sadar. The bulk soil $(110 \mathrm{Kg})$ was collected at a depth of $0-15 \mathrm{~cm}$. After collection, soil was prepared for initial chemical analysis in the laboratory of Soil Science Division, Bangladesh Institute of Nuclear Agriculture, Mymensingh. The unwanted materials like pebbles, plant roots, etc were removed from the bulk soil. The soil was dried in the sun and the clods were broken and followed by grinding and sieved with $2 \mathrm{~mm}$ sieve. The soil was silt loam in texture having $\mathrm{pH}$ 7.32. Initially chemical analysis was conducted to analyse this soil and found organic matter $1.92 \%$, total N 0.31\%, available P 19.4 ppm, exchangeable K $0.48 \mathrm{me} \%$, available S $19.2 \mathrm{ppm}$ and total As $54.54 \mathrm{ppm}$. Cowdung, poultry manure, wild aroids and water hyacinth were collected and kept in bucket for decomposition. After one month the organic manures were completely decomposed and then allowed to dry under sunlight. After drying, the composts were ground and sieved with $2 \mathrm{~mm}$ sieve. Finely ground sieved organic manures were kept in poly bag for initial chemical analysis and finally to use in pot for growing of rice. The chemical composition of different organic manures is presented in Table I.

A pot experiment was carried out at the net house of BINA, Mymensingh during January to May, 2004. Fifteen plastic pots were taken, those were $16 \mathrm{~cm}$ in diameter and $17 \mathrm{~cm}$ in height. Two and a half kg soil was taken in each pot and then the soil was mixed with organic manure and chemical fertilizer. There were all together 15 pots comprising 5 different treatments with 3 replications. There were five treatments in the experiment- $T_{1}$ : Control, $T_{2}$ : Cowdung, $T_{3}$ : Poultry manure, $\mathrm{T}_{4}$ : Water hyacinth compost and $\mathrm{T}_{5}$ : Wild aroids compost. The rate of compost application was $20 \mathrm{~g} /$ pot. Nitrogen ( $0.89 \mathrm{~g} / \mathrm{pot})$, phosphorus (0.238 g/pot), potassium ( $0.134 \mathrm{~g} / \mathrm{pot})$, sulphur $(0.279 \mathrm{~g} / \mathrm{pot})$ and zinc $(0.0043 \mathrm{~g} / \mathrm{pot})$ were applied from urea, TSP, MOP, gypsum and zinc oxide. Thirty days old healthy seedlings were transplanted in one hill at the central position of each pot. After transplanting 5$6 \mathrm{~cm}$ water was maintained in each pot throughout the growth period. Top dressing of urea was done at the maximum tillering and panicle initiation stages. The crop was harvested on 15 May, 2004 at maturity. Roots of rice plants were separated from the stem. The rice husks were separated from the rice grain. The different plant parts were analysed for N, P and K using standard methods (Page et al., 1982). The analysis of variance for nutrient concentration was done following the F-statistics. The mean comparisons of the treatments were made by the Duncan's Multiple Range test (DMRT) (Gomez and Gomez, 1984).

\section{Results and Discussion}

\section{Nitrogen concentration}

The treatments comprising different organic manures showed higher percentage of nitrogen in rice plant than the control treatment (Table II). Nitrogen concentration in rice grain ranged from $1.4 \%$ to $1.6 \%$. The highest $\mathrm{N}$ content in

Table I. Chemical properties of organic manure

\begin{tabular}{l|c|c|c|c|c}
\hline Organic manures & Total N (\%) & Total P (\%) & Total K (\%) & Total S (\%) & Total As (ppm) \\
\hline Cowdung & 2.64 & 0.93 & 1.66 & 0.06 & 0.69 \\
Poultry manure & 2.36 & 1.66 & 0.57 & 0.80 & 1.49 \\
Water hyacinth compost & 4.01 & 1.84 & 1.77 & 0.85 & 3.08 \\
Wild aroid compost & 2.29 & 0.58 & 1.56 & 0.22 & 0.79 \\
\hline
\end{tabular}


Table II. Effects of organic manure on $\mathrm{N}$ and $\mathrm{P}$ concentrations in grain, husk, straw and root of Boro rice

\begin{tabular}{|c|c|c|c|c|c|c|c|c|}
\hline \multirow[t]{2}{*}{ Treatment } & \multicolumn{4}{|c|}{ Nitrogen concentration (\%) } & \multicolumn{4}{|c|}{ Phosphorus concentration (\%) } \\
\hline & Grain & Husk & Straw & Root & Grain & Husk & Straw & Root \\
\hline $\mathrm{T}_{1}:$ Control & $1.40 \mathrm{~b}$ & $0.74 \mathrm{~b}$ & $0.61 \mathrm{~b}$ & $0.64 \mathrm{~b}$ & $0.17 \mathrm{~b}$ & $0.33 \mathrm{c}$ & 0.037 c & $0.46 \mathrm{c}$ \\
\hline $\mathrm{T}_{2}$ : Cowdung & $1.60 \mathrm{a}$ & $0.86 \mathrm{a}$ & $0.81 \mathrm{a}$ & $0.80 \mathrm{a}$ & $0.17 \mathrm{~b}$ & $0.44 \mathrm{a}$ & $0.041 \mathrm{c}$ & $0.54 \mathrm{~b}$ \\
\hline $\begin{array}{l}\mathrm{T}_{3}: \text { Poultry } \\
\text { manure }\end{array}$ & $1.46 \mathrm{~b}$ & $0.72 \mathrm{~b}$ & $0.67 \mathrm{~b}$ & $0.65 \mathrm{~b}$ & $0.17 \mathrm{~b}$ & $0.46 \mathrm{a}$ & 0.039 c & $0.47 \mathrm{c}$ \\
\hline $\begin{array}{l}\mathrm{T}_{4} \text { : Water } \\
\text { hyacinth compost }\end{array}$ & $1.56 \mathrm{a}$ & $0.86 \mathrm{a}$ & $0.77 \mathrm{a}$ & $0.71 \mathrm{~b}$ & $0.20 \mathrm{a}$ & $0.34 \mathrm{bc}$ & 0.088 a & $0.66 \mathrm{a}$ \\
\hline $\begin{array}{l}\mathrm{T}_{5}: \text { Wild aroid } \\
\text { compost }\end{array}$ & $1.41 \mathrm{~b}$ & $0.69 \mathrm{~b}$ & $0.64 \mathrm{~b}$ & $0.66 \mathrm{~b}$ & $0.18 \mathrm{ab}$ & $0.35 \mathrm{~b}$ & $0.072 \mathrm{~b}$ & $0.63 \mathrm{a}$ \\
\hline $\begin{array}{l}\text { Level of } \\
\text { significance }\end{array}$ & ** & * & ** & * & * & ** & ** & ** \\
\hline LSD Value & 0.084 & 0.1031 & 0.0595 & 0.084 & 0.0188 & 0.022 & 0.0072 & 0.0595 \\
\hline CV (\%) & 3.32 & 7.32 & 5.36 & 6.78 & 3.57 & 3.36 & 10.30 & 4.16 \\
\hline
\end{tabular}

Means followed by the same letter in a column are not significantly different by DMRT

$* *=$ Significant at $1 \%$ level of probability

*= Significant at $5 \%$ level of probability

$\mathrm{CV}(\%)=$ Co-efficient of variation

grain (1.6\%) was found in the treatment $\mathrm{T}_{2}$ that was statistically identical with treatment $\mathrm{T}_{4}$. The rest of the treatments were identical in grain- $\mathrm{N}$ concentration. In husk, nitrogen concentration ranged from 0.69 to $0.86 \%$ over the treatments. The highest $\mathrm{N}$ concentration in the husk $(0.86 \%)$ was found in the $\mathrm{T}_{2}$ and $\mathrm{T}_{4}$ treatments and was statistically superior to all other treatments. Nitrogen concentration in husk of $\mathrm{T}_{1}, \mathrm{~T}_{3}$ and $\mathrm{T}_{5}$ treatments were statistically similar. The $\mathrm{N}$ concentration in rice straw was significantly influenced by the application of different manures, ranging from $0.61 \%$ to $0.81 \%$. The highest $\mathrm{N}$ concentration was recorded in the treatment $T_{2}$, which was statistically similar to $T_{4}$ treatment. The lowest $\mathrm{N}$ concentration $(0.61 \%)$ was recorded in the control $\left(\mathrm{T}_{1}\right)$ treatment that was statistically similar to $\mathrm{T}_{3}$ and $\mathrm{T}_{4}$ treatments. In root, the maximum $\mathrm{N}$ concentration $(0.80 \%)$ was found in $\mathrm{T}_{2}$ treatment and it was statistically superior than all other treatments. The minimum $\mathrm{N}$ concentration (0.64\%) was found in $\mathrm{T}_{1}$ (control) treatment and was statistically identical with $\mathrm{T}_{3}, \mathrm{~T}_{4}$ and $\mathrm{T}_{5}$ treatments.

The increasing concentration of $\mathrm{N}$ in grain, husk, straw and root of organic manure treated pots indicate that organic manures increased availability of $\mathrm{N}$ in the soil which inturn increased the $\mathrm{N}$ contents in rice grain, straw and root (Khatik and Dikshil 2001). The higher $\mathrm{N}$ content in plant after organic manure application was also observed by Gupta (1979).
Nitrogen can be found in two significant forms in the compost. It can be present in the inorganic forms of nitrate nitrogen and ammonium nitrogen. In most of nitrogen in compost is bound within organic molecules. The nitrogen forms are immediately available for absorption by plants while the availability of the organic form depends on how rapidly the microorganism breakdown the compost. Nitrogen concentration was found more in grain than straw and root. The increasing effect of organic manures on the $\mathrm{N}$ content of grain and straw of rice was ranked in the order of cowdung $>$ water hyacinth compost $>$ poultry manure $>$ wild aroid compost.

\section{Phosphorus concentration}

The phosphorus concentration in grain, husk, straw and root was statistically influenced by different treatments (Table II). Phosphorus concentration in grain, husk, root and straw of rice was ranked in the order of root $>$ husk $>$ grain $>$ straw. In rice grain, highest $\mathrm{P}$ concentration $(0.20 \%)$ was observed in the treatment $T_{4}$ which was statistically identical to $T_{5}$ treatment. The treatments $T_{5}, T_{3}, T_{2}$ and $T_{1}$ had the identical $\mathrm{P}$ concentration in grain. In husk, $\mathrm{P}$ concentration ranged from 0.33 to $0.46 \%$ in different treatments. Maximum P concentration $(0.46 \%)$ was observed in treatment $T_{3}$ that was 
statistically identical to $\mathrm{T}_{2}$. The lowest husk $\mathrm{P}(0.33 \%)$ concentration was found in control treatment $\left(T_{1}\right)$, which was statistically identical to that found in $\mathrm{T}_{4}$ treatment. Highest $\mathrm{P}$ concentration in straw was observed in the $\mathrm{T}_{3}$ which was statistically superior to other treatments. Straw $\mathrm{P}$ concentration in $T_{5}$ was statistically superior to the $T_{1}, T_{2}$ and $T_{3}$ treatments. The lowest $\mathrm{P}$ concentration was observed in control treatment $\left(T_{1}\right)$, which was statistically identical to $T_{2}$ and $T_{3}$ and statistically inferior to the $\mathrm{T}_{4}$ and $\mathrm{T}_{5}$ treatments. In root, the highest $\mathrm{P}$ content $(0.66 \%)$ was noted from $\mathrm{T}_{4}$ treatment which was statistically similar to $T_{5}$ treatment. The treatment $T_{2}$ was statistically inferior to $T_{4}$ and $T_{5}$ treatments for $P$ concentration in root but superior to $T_{1}$ and $T_{3}$ treatments. The lowest $\mathrm{P}$ content $(0.46 \%)$ was recorded in control $\mathrm{T}_{1}$ treatment and statistically similar to $\mathrm{T}_{3}$ treatment. The highest phosphorus concentration in different treatments $\left(T_{4}\right.$ and $\left.T_{5}\right)$ over control $\left(\mathrm{T}_{1}\right)$ indicated that organic manures increased the $\mathrm{P}$ concentrations in rice grain, husk, straw and root. It may be due to increasing activity of alkaline phosphatase by the application of organic manure (Guan, 1989). Organic materials release phosphorus by mineralization and can improve phosphorus availability by reducing the tendency of the mineral fractions to fix phosphorus (Brady and Weil, 1996)

\section{Potassium concentration}

The concentration of $\mathrm{K}$ in gain, husk, root and straw was significantly influenced by the application of different manures (Table III). Among the different plant parts, the concentration of $\mathrm{K}$ was highest in straw followed by husk, root and grain. The highest value $(0.41 \%)$ was obtained from the treatment, which was superior to all other treatments. In husk, highest $\mathrm{K}$ concentration was found in $\mathrm{T}_{4}$ treatment, which was statistically similar to $T_{5}$ treatment. Again the treatment $T_{5}$ was statistically identical to that of $T_{3}$ treatment. The lowest potassium $(0.50 \%)$ content was found in $T_{1}$ treatment which was statistically similar to $T_{2}$ treatment. In straw, highest $\mathrm{K}$ concentration was observed in $\mathrm{T}_{5}$ treatment which was statistically identical to $T_{3}$ and $T_{4}$ treatments. The $K$ concentration in $T_{2}$ was statistically superior to $T_{1}$ treatment but inferior to $\mathrm{T}_{3}$ and $\mathrm{T}_{5}$ treatments. The lowest $\mathrm{K}$ concentration $(0.39 \%)$ was observed in $\mathrm{T}_{1}$ treatment (control). In root, highest $\mathrm{K}$ concentration $(0.66 \%)$ was recorded in $\mathrm{T}_{5}$ treatment, which was statistically identical to $\mathrm{T}_{4}$ treatment. Potassium content in $T_{2}$ and $T_{3}$ treatments was statistically similar and statistically superior to $\mathrm{T}_{1}$ treatment and statistically inferior to that of $\mathrm{T}_{4}$ and $\mathrm{T}_{5}$ treatments. The lowest $\mathrm{K}$ content was noted in $\mathrm{T}_{1}$ treatment (control) which was significantly inferior to all other treatments. Different treatments $\left(T_{2}, T_{3}, T_{4}\right.$ and $\left.T_{5}\right)$ showing apparently higher concen-

Table III. Effects of organic manure on $\mathrm{K}$ and $\mathrm{S}$ concentrations in grain, husk, straw and root of Boro rice

\begin{tabular}{l|c|c|c|c|c|c|c|c}
\hline \multirow{2}{*}{ Treatment } & \multicolumn{4}{|c|}{ Potassium concentration (\%) } & \multicolumn{4}{c}{ Sulphur concentration (\%) } \\
\cline { 2 - 9 } & Grain & Husk & Straw & Root & Grain & Husk & Straw & Root \\
\hline $\mathrm{T}_{1}$ : Control & $0.31 \mathrm{~b}$ & $0.50 \mathrm{c}$ & $0.39 \mathrm{c}$ & $0.33 \mathrm{c}$ & $0.057 \mathrm{c}$ & $0.035 \mathrm{~b}$ & $0.073 \mathrm{~d}$ & $0.047 \mathrm{~b}$ \\
$\mathrm{~T}_{2}$ : Cowdung & $0.31 \mathrm{~b}$ & $0.52 \mathrm{c}$ & $1.05 \mathrm{~b}$ & $0.44 \mathrm{~b}$ & $0.059 \mathrm{bc}$ & $0.036 \mathrm{~b}$ & $0.082 \mathrm{~cd}$ & $0.065 \mathrm{a}$ \\
$\mathrm{T}_{3}$ : Poultry manure & $0.34 \mathrm{~b}$ & $0.66 \mathrm{~b}$ & $1.66 \mathrm{a}$ & $0.50 \mathrm{~b}$ & $0.062 \mathrm{bc}$ & $0.040 \mathrm{a}$ & $0.089 \mathrm{bc}$ & $0.047 \mathrm{~b}$ \\
$\mathrm{~T}_{4}$ : Water & $0.34 \mathrm{~b}$ & $0.83 \mathrm{a}$ & $1.27 \mathrm{ab}$ & $0.61 \mathrm{a}$ & $0.072 \mathrm{a}$ & $0.056 \mathrm{a}$ & $0.107 \mathrm{a}$ & $0.063 \mathrm{a}$ \\
Hyacinth compost & & & & & & & & \\
$\mathrm{T}_{5}$ : Wild & $0.41 \mathrm{a}$ & $0.75 \mathrm{ab}$ & $1.66 \mathrm{a}$ & $0.66 \mathrm{a}$ & $0.064 \mathrm{~b}$ & $0.053 \mathrm{a}$ & $0.093 \mathrm{~b}$ & $0.055 \mathrm{ab}$ \\
aroid compost & & & & & & & & \\
Level of & $*$ & $* *$ & $* *$ & $* *$ & $* *$ & $* *$ & $* *$ & $* *$ \\
significance & & & & & & & & \\
LSD Value & 0.059 & 0.084 & 0.4946 & 0.059 & 0.0059 & 0.0065 & 0.0090 & 0.010 \\
CV (\%) & 7.32 & 6.48 & 21.69 & 6.77 & 4.49 & 7.82 & 2.22 & 6.60 \\
\hline
\end{tabular}

Means followed by the same letter in a column are not significantly different by DMRT

$* *=$ Significant at $1 \%$ level of probability

*= Significant at $5 \%$ level of probability

CV (\%) $=$ Co-efficient of variation 
tration of $\mathrm{K}$ in different parts of rice over control $\left(\mathrm{T}_{1}\right)$ indicated that organic manures helped in $\mathrm{K}$ uptake by rice. The nutrient of potassium is very important in compost. A high percentage of $\mathrm{K}$ nutrients is usually available to the plant at the first growing season. Mban et al. (2000) found higher K content in plots amended with cowdung, pig manure and poultry droppings relative to the unamended plots. It was observed that the $\mathrm{K}$ content in grain was lower than that of straw.

\section{Sulphur concentration}

The treatment with different types of manures had significant effect on S concentration in rice grain, husk, straw and root (Table III). The highest $S$ content $(0.072 \%)$ in grain was obtained in $\mathrm{T}_{4}$ treatment. The second highest $\mathrm{S}$ content $(0.064 \%)$ in grain was obtained in $T_{5}$ treatment which was statistically similar to $T_{3}$ and $T_{2}$ treatments. The lowest $S$ content $(0.057 \%)$ ingrain was obtained in $\mathrm{T}_{1}$ (control) treatment which was statistically inferior to $\mathrm{T}_{4}$ and $\mathrm{T}_{5}$ treatments. In husk, the $S$ concentration varied from 0.056 to $0.035 \%$. The maximum S $(0.056 \%)$ content was observed in $\mathrm{T}_{4}$ treatment that was statistically identical to $T_{5}$ and $T_{3}$ treatments. The minimum $S$ content was observed in $T_{1}$ (control) treatment, which was statistically identical to $T_{2}$ treatment. In straw, the highest $\mathrm{S}$ content $(0.017 \%)$ was observed $n T_{4}$ treatment. The second highest $\mathrm{S}$ concentration $(0.093 \%)$ was obtained in $T_{5}$ treatment, which was statistically similar to $T_{3}$ treatment. The lowest $\mathrm{S}$ content was obtained in $\mathrm{T}_{1}$ (control) treatment that was statistically similar to the $T_{2}$ treatment. In root, the $\mathrm{T}_{2}$ treatment contained highest $\mathrm{S}$ concentration, which was statistically similar to $T_{4}$ and $T_{5}$ treatments. Control treatment $T_{1}$ and $T_{3}$ treatments showed identical $S$ content in rice root. The results indicated that $\mathrm{S}$ content in grain, husk, straw and root of rice increased with the application of organic manures. Release of sulphur from organic matter usually constitutes the largest supply of sulphur to soil solution. Sulphur released from organic matter in oxidized to sulphate by sulphur-oxidizing microorganisms. This sulphate in the soil solution is immediately available for uptake. Kim et al. (1985) found increased S content with increasing rate of FYM.

\section{Conclusion}

Highest $\mathrm{N}, \mathrm{P}, \mathrm{K}$ and $\mathrm{S}$ concentration in grain were found $\mathrm{T}_{2}$, $\mathrm{T}_{4}, \mathrm{~T}_{5}$ and $\mathrm{T}_{4}$ treatments, respectively. In husk, highest concentration of $\mathrm{N}, \mathrm{P}, \mathrm{K}$ and $\mathrm{S}$ was obtained in $\mathrm{T}_{4}, \mathrm{~T}_{3}, \mathrm{~T}_{4}$, and $\mathrm{T}_{4}$ treatments, respectively. In root of rice, treatments $T_{2}, T_{4}, T_{5}$ and $\mathrm{T}_{2}$ had the highest amount of $\mathrm{N}, \mathrm{P}, \mathrm{K}$ and $\mathrm{S}$ concentration, respectively. In straw highest concentration of $\mathrm{N}, \mathrm{P}, \mathrm{K}$ and $\mathrm{S}$ was found in $\mathrm{T}_{2}, \mathrm{~T}_{4}, \mathrm{~T}_{5}$ and $\mathrm{T}_{4}$ treatments, respectively. So, it can be concluded that Organic manure is effective in arsenic contaminated soil where their application of organic manures increase $\mathrm{N}, \mathrm{P}, \mathrm{K}$ and $\mathrm{S}$ in rice grain, husk, straw and root. These increased nutrients in straw and root can be added again to soil by recycling. However, studies under field condition are necessary to validate the present findings and further investigation is needed to observe the effect of organic manures on rice grown on As contaminated soil and uncontaminated soil to make a comparison.

\section{Acknowledgement}

We wish to thank all staff members of the Soil Science Division, Bangladesh Institute of Nuclear Agriculture, Mymensingh, for their assistance and cooperation in performing analytical works during the research period. This study was financially supported by TWAS.

\section{References}

Ali M. M., Shaheed S. M. and Kubota D. (1997) Soil degradation during the period 1967-1995 in Bangladesh. II. Selected chemical characters. Soil Sci. Plant Nutr. 43: 879-890.

BBS (Bangladesh Bureau of Statistics) (2001) Yearbook of Agricultural Statistics of Bangladesh. Bangladesh Bureau of Statistics. Government of Bangladesh.

Biswas T., Bhattacharya P., Smith E., Huq S. M. I. and Naidu R. (2003) Bioaccumulation of arsenic in crops irrigated with groundwater with elevated arsenic levels in Bangladesh. Proceedings of the 7th International Conference on the Biochemistry of Trace Elements, Uppsala, Sweden, June 15-19.

Brady N. C. and Weil R. R. (1996) The Nature and Properties of Soils. 11th Edition, Prentice Hall, Upper Saddle River, New Jersey), pp 361, 473.

Cassman K. G., de Datta S. K., OlK D. C., Alcantra J., Sason M, Descalsota J. and Dizon M. (1997) Yield declined and the nitrogen economy of long-term experiment on continuing, irrigated rice system in the tropics. pp. 181222. In: R. Lal and B.A. Stewart (eds.) soil Management: Experimental Basis for sustainability and environmental quality. Lewis Publisher, London, UK. 
Dhar R. K., Biswas B. K., Samanta G., Mandal B. K., Chakraborti D., Roy S., Jafar A., Islam A., Ara G., Kabir S., Khan A. W., Ahmed S. A. and Hadi S. A. (1997) Groundwater arsenic calamity in Bangladesh. Current Science. 73: 48-59.

Gomez K. A. and Gomez A. A. (1984) Statistical Procedure for Agricultural Research. International Rice Research Institute, John Wiley and Sons, New York. pp. 139240.

Guan S. Y. (1989) Studies on the factors in influencing soil enzyme activities. I. Effects of organic manures on soil enzyme activities and $\mathrm{N}$ and $\mathrm{P}$ transformation. Acta Pedolotica Sinic. 26 (1): 72-78.

Gupta U. C. (1979) Boron nutrition of crops. Advances in Agronomy. 31: 273-307.

Fertilizer Recommendation Guide (2005). Bangladesh Agricultural Research Council (BARC). Farmgate. Dhaka. http://www.nawgbd.org/frg.htm, accessed on 30.05.07.

Rahman. M. M. and Moral M. J. B. (2006) Perception on agricultural inputs and environmental degradation. The Journal of Geo-Environment. 6: 20-27.

Hossain M. Z. (2001) Farmer's view on soil organic matter depletion and its management in Bangladesh. Nutrient cycling in Agroecosystems. 61: 197-204.

Hunter A. H. (1994) Soil fertility Analytical Service in Bangladesh. Consultancy Report. BARC, Dhaka.

Jackson M. L. (1973) Soil Chemical Analysis. Prentice Hall of India, Private Limited, New Delhi, India.
Khatik S. K. and Dikshit P. R. (2001) Integrated use of organic manures and inorganic fertilizers on yield, quality, economicas and nutrition of sunflower grown in Haplustert clay soil. Agricultural Science Digest. 21 (2): $87-90$

Kim B. Y., Hub B. L., Cho B. O., Park Y. and Lee B. N. (1985) Effect of different timing and rates of cattle manure application on rice yield in undeveloped paddy soil. Field Crops Abstract. 39 (8): 666.

Mban C. N., Okolo K. and Anikwe M. A. N. (2000) Changes in chemical and rheological properties of a sandy clay loam soil amended with organic wastes. Journal of Agricultural Technology and Education. 5 (1-2): 9-15.

MOA (Ministry of Agriculture) (1996) Bangladesh Food and Agriculture. World Food Summit, 13-17 November, Rome, Italy: 7.

Page A. L., Miller R. H. and Keeney D. R. (1982) In Methods of Soil Analysis, Part2: Chemical and Microbiological Properties. 2nd Ed. SSSA, Madison, Wisconsin.

Rezaenejad Y. and Afyuni M. (2001) Effect of organic matter on soil chemical properties and corn yield and element uptake. Journal of Science and Technology of Agricultural and Natural Resources. 4 (4): 19-29.

Received : May 04, 2008;

Accepted : July 09, 2009 